Cita: Martínez-Lemos, R.I.; Janura, M.; Abrantes, J.; Svoboda, Z.; García-García, O. (2019).

Acute neuromuscular responses in upper limb after nordic walking training in youth females. Cuadernos de Psicología del Deporte, 19(3), 168-178

\title{
Acute neuromuscular responses in upper limb after nordic walking training in youth females
}

\section{Respuesta neuromuscular aguda en extremidad superior tras entrenamiento de nordic walking en mujeres jóvenes}

\section{Resposta neuromuscular aguda no membro superior após treinamento de nordic walking em mulheres jovens}

\author{
Martínez-Lemos, R.I. ${ }^{1}$, Janura, M. ${ }^{2}$, Abrantes, J. ${ }^{3}$, Svoboda Z. ${ }^{2}$, García-García, O. ${ }^{1}$ \\ ${ }^{1}$ Sport Performance, Physical Condition and Wellness Lab, University of Vigo, Pontevedra, Spain \\ ${ }^{2}$ Department of Natural Sciences in Kinanthropology, Palacky University, Olomouc, Czech Republic \\ ${ }^{3}$ MovLab, Department of Arts and Information Technologies, Universidade Lusófona, Lisboa, Portugal
}

\begin{abstract}
Nordic walking (NW) is a practical form of healthy exercise. Up to now, few studies have been conducted on the non-clinical population and few has analysed muscular response after NW training. This study aimed to assess mechanical and neuromuscular changes of deltoideus and triceps brachii following short-term NW training. Twentyfour healthy and physically active females were randomly assigned to an NW group (NWG) $(\mathrm{n}=12)$ or control group $(\mathrm{n}=12)$. Training was carried out over a 6 -week period (18 sessions) on a treadmill $(4.5 \mathrm{~km} / \mathrm{h} ; 2 \%$ gradient). Mechanical and neuromuscular response was measured before and after training. Tensiomyography was used to assess maximum radial displacement, time contraction, time delay, sustain time, and half-relaxation time of deltoideus and triceps brachii. Heart rate (HR), and rating of perceived exertion (RPE) were used to control the training intensity. Mixed-design factorial analysis of variance (mixed ANOVA) was used to detect changes in the mechanical and neuromuscular characteristics after a NW training. During NW training, HR (115.83 bpm), 36.7\% of HR reserve and RPE (10.25) corresponding to light intensity were reported. After the training period, only a moderate increase $\left(6.25 \%, \mathrm{p}=0.02 ; \eta^{2}=0.06\right)$ in delay time for the triceps brachii were reported. A short-term and low to moderate intensity training conducted with a specific NW technique was not sufficient to modify the triceps brachii and deltoideus mechanical- neuromuscular response in healthy and young females.
\end{abstract}

Keywords: tensiomyography; walking with poles; upper extremity; neuromuscular assessment. 


\section{Nordic walking training in youth females}

\section{RESUMEN}

Nordic walking (NW) es una forma de ejercicio saludable. Hasta ahora pocos estudios han empleado poblaciones no clínicas y han analizado la respuesta muscular tras el entrenamiento de NW. Este estudio pretendió evaluar cambios mecánicos y neuromusculares en los músculos deltoideus y triceps brachii tras un entrenamiento breve de NW. Veinticuatro mujeres sanas y físicamente activias fueron asignadas aleatoriamente al grupo de $\mathrm{NW}(\mathrm{n}=12)$ o al grupo control $(\mathrm{n}=12)$. El entrenamiento se llevó a cabo durante un periodo de 6 semanas (18 sesiones) en un tapiz rodante $(4.5 \mathrm{~km} / ; 2 \%$ pendiente). La respuesta mecánica y neuromuscular fue medida antes y después del entrenamiento. Se empleó Tensiomiografía para evaluar el desplazamiento radial máximo, tiempo de contracción, tiempo de retardo, tiempo de espera y tiempo medio de relajación del deltoideus y triceps brachii. La intensidad del entrenamiento se controló a través de la frecuencia cardíaca (FC) y la tasa de esfuerzo percibido (TEP). Se empleó análisis factorial de la varianza (ANOVA mixto) para detectar cambios en las características mecánicas y neuromusculares tras el entrenamiento de NW. Durante el entrenamiento de NW, se registró una FC (115.83 ppm), un porcentaja de la FC de reserva (37\%) y una tasa de esfuerzo percibido (10.25) correspondiente a un nivel ligero de intensidad. Tras el período de entrenamiento, sólo se registró un incremento moderado en el tiempo de retardo $\left(6.25 \%, \mathrm{p}=0.02 ; \eta^{2}=0.06\right)$ para el triceps brachii. Un entrenamiento de NW breve de entre baja y moderada intensidad con una técnica específica no ha sido suficiente como para modificar la respuesta mecánica y neuromuscular del triceps brachii y deltoideus en mujeres jóvenes sanas.

Palabras clave: tensiomiografía; marcha con bastones, extremidad superior; evaluación neuromuscular.

\section{RESUMO}

A caminhada nórdica ou de acordo com a designação anglo-saxónica, Nordic walking (NW) é um modo prático de realizar exercício saudável. Até o momento, poucos estudos foram conduzidos em população não clínica e igualmente, poucos estudos analisaram a resposta muscular após o treino de NW. O atual estudo teve como objetivo avaliar as alterações mecânicas e neuromusculares do deltoide e do tríceps braquial, após o treino de curta duração do NW. Vinte e quatro mulheres saudáveis e fisicamente ativas foram aleatoriamente designadas para dois grupos: 0 grupo que treinou NW (NWG) $(\mathrm{n}=12)$ e o grupo de controlo $(\mathrm{n}=12)$. O treino foi realizado em passadeira rolante (4,5 km / h; inclinação de 2\%) durante um período de 6 semanas (18 sessões). A resposta mecânica e neuromuscular foi avaliada antes e após cada sessão de treino. A tensiomiografia foi usada para medir no deltóide braquial e no tríceps braquial, o valor máximo da contração muscular, o tempo de contração, o tempo de atraso, o tempo de sustentação e o tempo de relaxamento. Para controlar a intensidade do treino foram usados a frequência cardíaca (FC) e a perceção subjetiva do esforço realizado (RPE). A análise fatorial de variância (ANOVA mista) foi usada para detetar alterações nas características mecânicas e neuromusculares após um treino de NW. Durante o treino de NW, HR $(115,83 \mathrm{bpm}), 36,7 \%$ da FC de reserva e RPE $(10,25)$ correspondentes à intensidade da luz foram registados. Após o período de treino, apenas foi registado um aumento moderado do tempo de atraso do tríceps braquial (6,25\%, $\mathrm{p}=0,02 ; \eta 2=0,06)$. O treino de curta e moderada intensidade, realizado com uma técnica específica de NW, não foi suficiente para modificar respostas mecânicas e neuromusculares do deltoide e do tríceps braquial em mulheres saudáveis e jovens.

Palavras-chave: Tensiomiografia; Caminhar com bastões; Membro superior; Avaliação neuromuscular. 


\section{Martínez-Lemos, R.I.; Janura, M.; Abrantes, J.; Svoboda, Z.; García-García, O.}

\section{INTRODUCTION}

Nordic walking (NW) is a fitness activity that uses specially designed poles to engage the upper body's musculature and provides both a cardio and strength workout simultaneously (Nottingham, 2002). NW requires only three basic functional capacities: walking, trunk mobility and handgrip. In addition, it is easy to learn, can be done throughout the year and can be enjoyed at any age and any fitness level. Originally, there were two main ways to walk with poles: Exerstriding $^{\mathrm{TM}}$, almost exclusively in United States from the 1980s, and NW proper, developed in Finland in the 1990s and identified with the International Nordic Walking Association (INWA), Over the years, several other educational organisations have emerged along with variations in NW techniques. That is the case with the International Nordic Fitness Organisation (INFO) with the ALFA technique (Svensson, 2009).

In recent years, several reviews had reported the positive effects of NW as a form of rehabilitation, as a well-tolerated and safe exercise even as a primary and secondary prevention instrument (Martínez-Lemos, García-García and Serrano-Gómez, 2011; Morgulec, 2011; Fritschi, Brown, Laukkanen and Uffelen, 2012; Tschentscher, Niederseer and Niebauer, 2013. One of these reviews concluded that NW is an emerging field of research in which the people without diagnosed conditions were underrepresented, and suggested an exploration of this topic on these populations (Fritschi, Brown, Laukkanen and Uffelen, 2012). Up until now, few studies have been conducted on the non-clinical population and only four were truly experimental designs. They were focused in middle-aged women with health problems, such as obesity (Figard-Fabre, Fabre, Leonardi and Schena, 2011) or sedentary behaviour (KukkonenHarjula et al., 2007) and a special health situation such as menopause (Hagner, Hagner-Derengowska, Wiacek and Zubrzycki, 2009; Saulicz et al., 2015). The remaining studies including healthy females-all of them-were observational designs and the most frequently examined physical outcomes were cardiorespiratory measures, mainly $\mathrm{VO}_{2 \max }$, through a submaximal test.

Upper body engagement is one of the most promising characteristics of NW, and several studies have reported increased upper body muscle involvement performing NW (Shim et al., 2013; Sugiyama, Kawamura, Tomita and Katamoto, 2013; Pellegrini et al., 2015). All were crosssectional studies conducted with electromyography; therefore, there was no possibility to report muscular changes. Recently, a new, non-invasive and valid technique (tensiomyography-TMG) has been proposed for assessing mechanical and neuromuscular response (Šimunič, 2012). TMG gives an assessment of the contractile properties of superficial muscles. This technique overcomes the difficulty of determining the performance of each muscle within a muscle group and provides relevant information on several aspects such as muscle tone and changes in the diameter of the muscle fibre (Pišot et al., 2008), distribution of muscle fibre types (Dahmane, Djordjevič, Šimunič, Valenčič, 2005; Šimunič et al., 2011), assessment of sporting populations, muscle fatigue, recovery and symmetry (Macgregor, Hunter, Orizio, Fairweather \& Ditroilo, 2018), muscle injuries control (García-García, Hernández-Mendo, Serrano-Gómez, Morales-Sánchez, 2013) or the relationship between TMG parameters and potential predictors of performance (García-García, CubaDorado, Fernández-Redondo \& López-Chicharro, 2018) and the contractile properties of women muscles (GarcíaGarcía, Serrano-Gómez and Martínez-Lemos, 2011; García-García, Cancela-Carral y Huelin-Trillo, 2015), However, an assessment of the contractile properties of the upper body muscles engaged in NW is lacking.

Therefore, there is still limited evidence regarding muscular effects after NW training in healthy youths, especially in females. In addition, to our knowledge tensiomyography response to $\mathrm{NW}$ have never been reported. In this context, the purpose of this study was to assess selected upper-body muscular changes following a short-term NW training in healthy young females.

\section{MATERIAL AND METHODS}

\section{Participants}

Twenty-four young females were selected for this study. To ascertain the random sampling, we recruited the volunteers via an advertisement on a university website for two weeks. They had to meet the following eligibility criteria: female, non-smoking, body mass index (BMI) $<30 \mathrm{~kg} / \mathrm{m}^{2}$; not pregnant or breastfeeding; no previous experience in NW practice; no participation in any other current supervised exercise programme and no prescribed drugs affecting HR. After two weeks 125 contacts answered the advertisement of which 83 met the inclusion criteria and passed prescreening to assess the homogeneity of participants. This process was conducted using three self-report questionnaires online to determine health, readiness for exercise and physical activity (PA) related eligibility: (1) PA readiness questionnaire (PAR-Q), (2) stages of change for PA behaviour questionnaire and (3) health self-report by means of SF-12 questionnaire. Readiness for exercise was defined as having answered no to all PAR-Q questions. A 'physically active subject' was defined as being in one of the three active stages of changes PA behaviour (preparation, action or maintenance). A 'healthy subject' was defined as being in excellent, very good or good selfreported health. Fifty-nine persons were excluded due to their not meeting the eligibility criteria, and 24 females were finally accepted to participate in the study. They were 


\section{Nordic walking training in youth females}

randomly assigned to an NW group $(\mathrm{NWG})(\mathrm{n}=12)$ that performed the 6 weeks NW program, or the control group (CG) $(\mathrm{n}=12)$, that followed your daily habits. Participants were informed of the purpose of the study and the associated risks before providing their informed consent. The study protocol was conducted in accordance with the ethical principles of the Declaration of Helsinki and approved by the institutional ethics committee.

\section{Instruments}

Height and weight were measured with the participant wearing light clothing and with their shoes off using a portable stadiometer (SECA ${ }^{\circledR}$, Mod. 217, Germany) and digital scales (SECA ${ }^{\circ}$, Mod. 899, Germany), respectively. BMI was calculated by dividing body weight $(\mathrm{kg})$ by squared height $\left(\mathrm{m}^{2}\right)$. Heart rate in beats per minute $(\mathrm{bpm})$ was controlled with a monitor (Polar S810, Polar Electro Oy, Kempele, Finland) and was recorded continuously during the entire intervention. Maximal heart rate (MHR) was estimated with a specific equation for females [MHR= 206-(0.88-age)] because there is a strong, linear relationship between age and peak HR $(\mathrm{p}<0.001)$ achieved with exercise stress testing (Gulati et al., 2010). The participants were instructed to record the supine resting $\mathrm{HR}$ on three successive mornings at the same time also to calculate HR reserve $[\mathrm{HR}$ reserve $=(\mathrm{MHR}-$ Resting $\mathrm{HR})]$. In addition, $\mathrm{VO}_{2 \max }$ was estimated indirectly with equation $\left[\mathrm{VO}_{2 \max }=15\right.$. $\left.\left(\mathrm{HR}_{\max } / \mathrm{HR}_{\text {resting }}\right)\right]$ from maximum and resting $\mathrm{HR}$, which has shown accuracy comparable with other common $\mathrm{VO}_{2 \max }$ tests (Uth, Sørensen, Overgaard and Pedersen, 2004). They were advised not to follow the HR monitor's display during training. They were also instructed on how to rate exertion on the Borg's Rating of Perceived Exertion (RPE) scale ranging from 6 to 20 (Borg, 1982), separately, for every one of the three 30-min set sessions, and the weighted mean of three measures was calculated.

Neuromuscular and mechanical responses of triceps brachii (TB) and deltoideus (DE) were assessed using TMG following the protocol described by García, Cancela and Trillo (2015), Radial displacement of the muscle belly was evaluated using a digital transducer (GK 30 Panoptik doo, Ljubljana, Slovenia), which was placed perpendicular to the thickest part of the muscle belly and was marked using a skin marker, in accordance with the protocol suggested by Perotto, Delagi, Lazzeti and Morrison (2005). TB: Immediately posterior to the insertion of deltoid or deltoid tubercle. DE: Halfway between the tip of the acromion and the deltoid tubercle. Self-adhesive electrodes $(5 \times 5 \mathrm{~cm}, \mathrm{AB}$ Cefar-Compex Medical Co., Ltd., Malmo, Sweden) were placed symmetrically spaced $5 \mathrm{~cm}$ sensor (Figure 1).

Time-displacement curves were obtained through electrical stimulation lasting $1 \mathrm{~ms}$. A total of 19 curves were obtained for each measured muscle of each participant. Only the maximal radial displacement curve of muscle evaluated was selected for further analysis. In each measurement the following parameters were obtained: maximal radial displacement of the muscle $\left(\mathrm{D}_{\mathrm{m}}\right)$ measured in $\mathrm{mm}$; time contraction $\left(T_{c}\right)$ determined between 10 and $90 \%$ maximal response measured in $\mathrm{ms}$; time delay $\left(\mathrm{T}_{\mathrm{d}}\right)$ determined between 0 and $10 \%$ of the maximum response; Radial displacement velocity $\left(V_{c}\right)$ as the rate $\left(\mathrm{mm} \cdot \mathrm{s}^{-1}\right)$ between the radial displacement occurring during the time period of $\mathrm{T}_{\mathrm{c}}$ $\left(D_{m} 80\right)$ and $T_{c}\left[D_{m} 80 / T_{c}\right]$. In order to determine the reproducibility of the data, two measurements of the two muscles were tested for each participant. The time between the first and second measurement was between 10 and 15 min. All participants were healthy and did not perform strenuous exercise 72 hours prior to each assessment. An experienced researcher with 10 years of TMG practice performed the neuromuscular and mechanical responses assess.

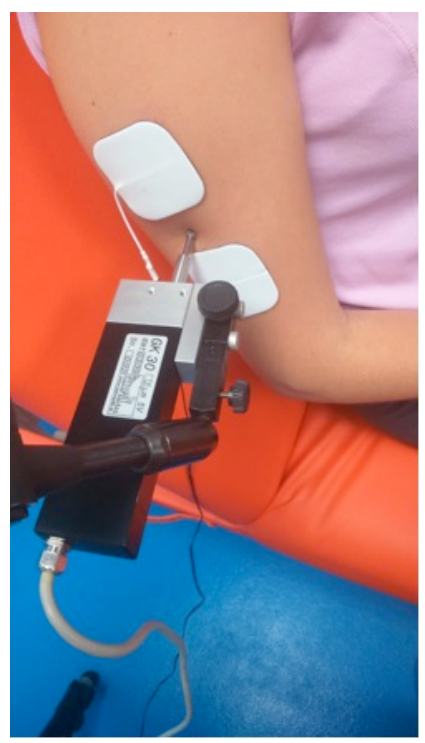

Figure 1. - Image showing triceps brachii neuromuscular and mechanical response assess by tensiomyography (TMG). The initial stimulus intensity was $20 \mathrm{~mA}, 5 \mathrm{~mA}$ on increasing until the maximum intensity of the electro -S2 TMG (EMF- FURLAN \& Co. doo, Ljubljana, Slovenia), located at $110 \mathrm{~mA}$. The deltoideus and triceps brachii muscles of both arms were assessed static and relaxed, with the participant seated, the back supported and the elbow flexed to $100^{\circ}$.

\section{Procedures}

Participants came to the laboratory regularly for ten weeks: the first week for baseline measures (T1), the second and third to learn NW technique on the treadmill (3/week), the fourth to the ninth to train (2/week), and the final week for post-training measurements (T2). After baseline measures, the NWG were tutored by a NW master instructor for 90min sessions using a proven and structured teaching method based on the guidelines of INFO. The four main principles of the ALFA functional NW technique are the following 


\section{Martínez-Lemos, R.I.; Janura, M.; Abrantes, J.; Svoboda, Z.; García-García, O.}

(Wilhelm, Neureuther and Mittermaier, 2009): (a) walk upright; (b) long arm movements; (c) the triangle; and (d) adapt step. All sessions of the training period were performed at the same time of day for each participant $( \pm 30$ min) in a climate-controlled laboratory. Participants in the NWG performed twice weekly on non-consecutive days for 6 weeks. The training session lasted 135 min and included: 15 min warm-up off the treadmill, 90 min NW training on the treadmill ( 30 min for 3 sets with 5 minute rests between sets) and 15 min of cooling down off the treadmill.

Training intensity was defined by treadmill speed and gradient. This setting was based on subjective perception of exertion by means of RPE and HR monitoring during the learning period. The final speed setting $\left(4.6 \mathrm{~km} \cdot\right.$ hour $^{-1}=$ $76.6 \mathrm{~m} / \mathrm{min}$ ) and gradient $(2 \%)$ constant were considered as endurance without the risk of participants falling. The motorised treadmill (Jaeger LE 300 C, Germany) had a 92 $\mathrm{cm}$ wide by $160 \mathrm{~cm}$ long walking deck. NW poles (Leki, Speed Pacer Vario, Leki Co., Germany) weighing approximately $0.45 \mathrm{~kg}$ with an adjustable strap, ergonomic grip and asphalt paw. The length of the NW poles was adjusted for all participants by multiplying the subject's height by 0.7 (Wilhelm, Neureuther and Mittermaier, 2009). During the study, the participants were asked not to change any lifestyle habits, nutrition and physical activity routines. Before and after intervention, resting HR and MNR were measured using standardised procedures. During the intervention ( 6 weeks), intensity was controlled using both subjective (RPE) and objective (HR) measures.

\section{Statistical analysis}

The normality distribution of the data was checked by means of the Kolmogorov-Smirnov test. The criterion reference for statistical significance was set at $\mathrm{p}<0.05$ and results were expressed as means \pm SD. The intra-class correlation coefficients (ICC) analysis, using single rater measurement, two-way mixed effects model and absolute agreement of TMG parameters were assessed, using two measurements of each participant with a confidence interval (CI) of $95 \%$. ICC $>0.8$ was interpreted as good reliability, while ICC $<0.8$ reflected insufficient reliability (Atkinson and Nevill, 1998). To determine the difference between left and right sides a $t$ test for paired samples was conducted. Mixed-design factorial analysis of variance (mixed ANOVA) was used to detect changes in the mechanical and neuromuscular characteristics after a NW training. Two factors were included in the mixed-design ANOVA model. Time (changes detected between assessment point 1 and 2) was used as the within-subjects variable and group (NWG vs CG) was used as the between-subjects variable. Bonferroni post hoc tests with adjustment for $95 \%$ confidence intervals were used to compare the main effects and identify significant individual differences. The effect sizes in mixed-design ANOVA were reported as partial eta square $\left(\eta^{2}\right)$ and interpreted as small $(0.01)$, moderate $(0.06)$ or large (0.14) (Cohen, 1988). The percentage differences in TMG parameters between the two assessments points in the muscles were also calculated and interpreted based on detectable change in the parameters. An alpha level of $\mathrm{p}<.05$ was considered statistically significant. All data were analysed using SPSS v19.0 for Windows (SPSS Inc., Chicago, IL, USA).

\section{RESULTS}

All of the 24 women completed the study and there no were dropouts or exclusions for any reason. No participant on NWG reported negative effects of exercise (muscle pain or fatigue) in the course of the training. Characteristics of the study population are shown in Table 1. No significant differences were observed between groups, and therefore, they were considered as homogeneous. During NW training means and range for objective intensity were HR (115.83 \pm $15.86 \mathrm{bpm})$, maximal HR $(49.87 \pm 16.10 \%)$ and reserve HR $(36.94 \pm 10.65 \%)$, whereas for subjective intensity the RPE was $10.25 \pm 1.05$ points based on an original scale of $6-20$ (Table 2). ICC scores reported $(0.81-0.97$; 95\% CI) for TMG, were interpreted to reflect good reliability. The highest ICC $(0.90-0.97)$ was obtained for $\mathrm{T}_{c}$ and $\mathrm{D}_{\mathrm{m}}$ while the lowest ICC (0.89) was obtained for $T_{d}$. No significant differences were found in any TMG parameter of deltoideus and triceps brachii for either side, so the values shown correspond to the mean of both arms. After 6 weeks, as shown in Table 3 , there were no statistically significant differences intra-subjects (before vs. after) or inter-subjects (NWG vs. CG) for deltoideus. For triceps brachii, a moderate increase $\left(6.25 \%, \mathrm{p}=0.02, \eta^{2}=0.06\right)$ after training was observed in delay time $\left(\mathrm{T}_{\mathrm{d}}\right)$ for NWG. However, $\mathrm{T}_{\mathrm{c}}$ and $\mathrm{D}_{\mathrm{m}}$ of both muscles have shown an increase with a lowmoderate effect.

\section{DISCUSSION}

The present study indicates that 6-week light-intensity NW training was not sufficient to achieve changes in MNR of selected upper-body muscles in healthy and young females. To our knowledge, this is the first study conducted with ALFA-functional NW technique and the first to assess muscular properties with TMG after NW training. NW is an aerobic activity for outdoor training; nevertheless, the use of treadmill has made it possible to control critical variables such as training load, dose and walking surface. However, the NW technique on a standard treadmill could be not representative of that used by most people in recreational over-ground NW (Church, Earnest and Morss, 2002). To clarify this topic, a recent study, also conducted with young and healthy people, aimed to compare the physiological response between NW on a specially 


\section{Nordic walking training in youth females}

designed treadmill and NW on a level over-ground surface. The conclusion was that over-ground NW created a greater physiological stress than treadmill NW performed at the same speed and distance. This difference may be due to the relatively narrow walking and poling decks on the treadmill,

Table 1. Baseline characteristics of the participants (data are presented as mean $\pm S D$ ).

\begin{tabular}{lcccc}
\hline Characteristics & $\begin{array}{c}\text { Total } \\
(\mathrm{n}=24)\end{array}$ & $\begin{array}{c}\text { NWG } \\
(\mathrm{n}=12)\end{array}$ & $\begin{array}{c}\text { CG } \\
(\mathrm{n}=12)\end{array}$ & P-value $^{I}$ \\
\hline Age (years) & $20.52 \pm 2.06$ & $21.33 \pm 2.06$ & $20.15 \pm 2.03$ & 0.258 \\
Weight $(\mathrm{kg})$ & $57.48 \pm 7.64$ & $56.10 \pm 12.44$ & $58.12 \pm 4.67$ & 0.903 \\
Height $(\mathrm{cm})$ & $161.84 \pm 5.20$ & $163.33 \pm 5.27$ & $161.15 \pm 5.24$ & 0.848 \\
BMI $\left(\mathrm{kg} \cdot \mathrm{m}^{-2}\right)$ & $21.92 \pm 2.55$ & $20.84 \pm 3.26$ & $22.42 \pm 2.11$ & 0.412 \\
HR & $73.42 \pm 5.89$ & $73.00 \pm 9.63$ & $73.61 \pm 3.64$ & 0.839 \\
HSP $(0-5)$ & $2.47 \pm 0.61$ & $2.46 \pm 0.66$ & $2.50 \pm 0.54$ & 0.903 \\
SOCPA $(0-5)$ & $3.57 \pm 1.16$ & $3.50 \pm 1.22$ & $3.61 \pm 1.19$ & 0.848 \\
\hline
\end{tabular}

Standard deviation (SD); Body mass index (BMI); Health self-perceived (HSP) describe five stage; $1=$ wrong, $2=$ regular, $3=$ good, $4=$ very good and $5=$ excellent. Stage of change for physical activity (SOCPA) describe five stage of change behaviour for PA; $1=$ Precontemplators: inactive and not thinking of becoming active, $2=$ Contemplators: inactive but are thinking about becoming active, $3=$ Preparers: intend to be physically active in the next month or have unsuccessfully taken action in the past year, $4=$ Action: physically active at the recommended levels but have been active for less than six months, and 5=Maintenance: physically active at the recommended levels and have been active for six or more months.; $N W G$ ( Nordic walking group); CG (control group). " " $t$ " Test for compare means.

Table 2. Subjective and objective intensity report during NW training as variable control

\begin{tabular}{cccccc} 
& \multicolumn{5}{c}{ Nordic Walking Group $(\mathrm{n}=12)$} \\
\hline & Mean \pm SD & Range & Min & Max & Variance \\
\hline Objective Intensity & & & & & \\
HR (bpm) & $115.83 \pm 15.86$ & 43.0 & 99.0 & 142.0 & 251.76 \\
$\mathrm{HR}_{\max }(\%)^{1}$ & $49.87 \pm 10.65$ & 41.90 & 35.80 & 77.70 & 259.47 \\
$\mathrm{HR}_{\text {reserve }}(\%)^{2}$ & $36.94 \pm 10.65$ & 29.28 & 26.92 & 56.20 & 113.62 \\
Subjective Intensity & & & & 1.01 \\
$\mathrm{RPE}^{3}$ (points) & $10.25 \pm 1.05$ & 2.26 & 9.11 & 11.37 & 1.01 \\
\hline
\end{tabular}

${ }^{T} H$ Rmax $=\%[(206-0.88) \cdot$ age $] ;{ }^{2} H$ Rmax $=\%[$ (Resting HR $)-(220$-age $\left.)\right] ;{ }^{3}$ Rate of perceived exertion 


\section{Martínez-Lemos, R.I.; Janura, M.; Abrantes, J.; Svoboda, Z.; García-García, O.}

Table 3. Results of mechanical muscle response assess. TMG parameters values for both arms, pre and post NW training $($ mean $\pm S D)$

\begin{tabular}{|c|c|c|c|c|c|c|c|c|}
\hline Variable & Group & Before NW & After NW & Dif $(\%)$ & $\eta 2$ & $\begin{array}{c}\text { Time(intraS) } \\
\text { F-p }\end{array}$ & $\begin{array}{c}\text { Group (interS) } \\
\text { F-p }\end{array}$ & $\begin{array}{c}\text { Time } x \\
\text { group F-p }\end{array}$ \\
\hline \multicolumn{9}{|l|}{ Deltoideus } \\
\hline \multirow[t]{2}{*}{$\mathrm{Tc}(\mathrm{ms})$} & NWG & $15.2 \pm 1.5$ & $16.3 \pm 1.9$ & $7.2 \%$ & \multirow{2}{*}{0.11} & $\mathrm{~F}=0.823$ & \multirow{2}{*}{$\begin{array}{l}F=0.035 \\
p=0.854\end{array}$} & \multirow{2}{*}{$\begin{array}{l}F=1.177 \\
p=0.301\end{array}$} \\
\hline & CG & $15.5 \pm 1.3$ & $15.8 \pm 0.9$ & $1.9 \%$ & & $\mathrm{p}=0.384$ & & \\
\hline \multirow[t]{2}{*}{$\operatorname{Dm}(\mathrm{mm})$} & NWG & $5.4 \pm 2.3$ & $6.3 \pm 3.9$ & $16.6 \%$ & \multirow[b]{2}{*}{0.04} & $\mathrm{~F}=0.10$ & \multirow{2}{*}{$\begin{array}{l}F=0.056 \\
p=0.817\end{array}$} & \multirow{2}{*}{$\begin{array}{l}F=0.193 \\
p=0.669\end{array}$} \\
\hline & $\mathrm{CG}$ & $5.5 \pm 1.3$ & $5.4 \pm 1.6$ & $-1.8 \%$ & & $\mathrm{p}=0.921$ & & \\
\hline \multirow[t]{2}{*}{$\mathrm{Td}(\mathrm{ms})$} & NWG & $17.2 \pm 0.1$ & $17.4 \pm 0.9$ & $1.1 \%$ & \multirow{2}{*}{0.02} & $F=1.646$ & \multirow{2}{*}{$\begin{array}{l}F=0.708 \\
p=0.418\end{array}$} & \multirow{2}{*}{$\begin{array}{l}F=0.508 \\
p=0.491\end{array}$} \\
\hline & CG & $16.9 \pm 0.8$ & $17.2 \pm 0.8$ & $1.7 \%$ & & $\mathrm{p}=0.226$ & & \\
\hline \multirow{2}{*}{$\begin{array}{r}\mathrm{Vc} \\
\left(\mathrm{mm} \cdot \mathrm{s}^{-1}\right)\end{array}$} & NWG & $280 \pm 130$ & $270 \pm 190$ & $-3.5 \%$ & \multirow[b]{2}{*}{0.01} & $\mathrm{~F}=0.581$ & \multirow{2}{*}{$\begin{array}{l}\mathrm{F}=0.001 \\
\mathrm{p}=0.990\end{array}$} & \multirow{2}{*}{$\begin{array}{l}F=0.180 \\
p=0.679\end{array}$} \\
\hline & $\mathrm{CG}$ & $290 \pm 70$ & $270 \pm 80$ & $-6.8 \%$ & & $\mathrm{p}=0.461$ & & \\
\hline \multicolumn{9}{|c|}{ Triceps brachii } \\
\hline \multirow[t]{2}{*}{$\mathrm{Tc}(\mathrm{ms})$} & NWG & $17.9 \pm 2.2$ & $20.2 \pm 5$ & $12.8 \%$ & \multirow{2}{*}{0.15} & $\mathrm{~F}=2.889$ & \multirow{2}{*}{$\begin{array}{l}F=0.000 \\
p=0.992\end{array}$} & \multirow{2}{*}{$\begin{array}{l}F=2.277 \\
p=0.157\end{array}$} \\
\hline & $\mathrm{CG}$ & $22.2 \pm 13.4$ & $19.3 \pm 2.8$ & $-13 \%$ & & $\mathrm{p}=0.115$ & & \\
\hline \multirow[t]{2}{*}{$\operatorname{Dm}(\mathrm{mm})$} & NWG & $8 \pm 0.9$ & $8.9 \pm 1.1$ & $11.2 \%$ & \multirow{2}{*}{0.02} & $\mathrm{~F}=2.086$ & \multirow{2}{*}{$\begin{array}{l}F=2.336 \\
p=0.155\end{array}$} & \multirow{2}{*}{$\begin{array}{l}F=0.327 \\
p=0.579\end{array}$} \\
\hline & $\mathrm{CG}$ & $9.2 \pm 1.8$ & $9.5 \pm 1.9$ & $3.2 \%$ & & $\mathrm{p}=0.177$ & & \\
\hline \multirow[t]{2}{*}{$\mathrm{Td}(\mathrm{ms})$} & NWG & $19.2 \pm 1.6$ & $20.4 \pm 1.6^{*}$ & $6.25 \% *$ & \multirow{2}{*}{0.06} & $\mathrm{~F}=6.874$ & \multirow{2}{*}{$\begin{array}{l}F=0.603 \\
p=0.452\end{array}$} & \multirow{2}{*}{$\begin{array}{l}F=0.719 \\
p=0.413\end{array}$} \\
\hline & $\mathrm{CG}$ & $20.7 \pm 3.2$ & $21.5 \pm 2.7$ & $3.8 \%$ & & $\mathrm{p}=0.022$ & & \\
\hline \multirow{2}{*}{$\begin{array}{r}\mathrm{Vc} \\
\left(\mathrm{mm} \cdot \mathrm{s}^{-1}\right)\end{array}$} & NWG & $360 \pm 50$ & $340 \pm 90$ & $-5 \%$ & \multirow[b]{2}{*}{0.001} & $\mathrm{~F}=1.857$ & \multirow{2}{*}{$\begin{array}{l}F=4.536 \\
p=0.060\end{array}$} & \multirow{2}{*}{$\begin{array}{l}F=0.024 \\
p=0.879\end{array}$} \\
\hline & $\mathrm{CG}$ & $430 \pm 60$ & $420 \pm 40$ & $-2.3 \%$ & & $\mathrm{p}=0.200$ & & \\
\hline
\end{tabular}

Contraction time (Tc), maximal radial displacement (Dm), delay time (Td), radial displacement velocity (Vc). Mean, SD, \% differences and effect size $\left(\eta^{2}\right)$, Mixed Analysis of Variance (ANOVA) $p<0.05\left(^{*}\right)$ 


\section{Nordic walking training in youth females}

which made it difficult for the participants to place their poles correctly and maintain a consistent walking pattern. Increasing the width of the decks could eliminate the discrepancy (Dechman, Appleby, Carr and Haire, 2012). This previous evidence advises us to use a comfortable treadmill regarding walking area, and to include a long learning period with a supervised teaching method by a master NW instructor.

There are also serious differences between NW techniques, and therefore, the training effects may differ depending on techniques and poles used, something that was reported by a recent review (Fritschi, Brown, Laukkanen and Uffelen, 2012). As all modify motor pattern, NW must be learning, because take a poles and walking with them spontaneously is not equal to perform NW, something that has already been reported by one of the few studies that included details of the technique used as well as learning and evaluation process (Figard-Fabre, Fabre, Leonardi and Schena, 2010). In our study we have tried to control these three critical variables: treadmill, NW technique and learning process.

Taking into account that means of RPE and reserve HR (\%) in our study were within range of light exercise intensity (10-11 points RPE and 20-59\% reserve HR) following the standard classification for healthy adults, we can conclude that this kind of workout is close to the recommendation for health-enhancing physical activity for adults (Haskell et al., 2007).

A good reproducibility in TMG parameters has been reported using the ICC with $95 \%$ confidence interval (CI) by Martín-Rodríguez, Loturco, Hunter, Rodríguez-Ruiz \& Munguía-Izquierdo (2017). Considering an ICC of 0.8 reflecting a good reproducibility, and a lower value as insufficient reproducibility (Atkinson and Nevill, 1998), it can be said that in this case, good reproducibility is confirmed, on the same day, for the TMG assessment. For NWG, the training programme appears to have produced a slight increase in TMG parameters, although not significant, after the intervention at triceps brachii and deltoideus. The values of $\mathrm{T}_{\mathrm{c}}$ and $\mathrm{T}_{\mathrm{d}}$ that are not significant, except for the triceps brachii $\mathrm{T}_{\mathrm{d}}(6.25 \% ; \mathrm{p}=0.02)$, and a small or large effect size $\left(\eta^{2}\right.$ between 0.02 and 0.15$)$. One possible explanation is that the training programme caused a slight increase in motor units of slow fibres type I (slow), which occurred as a result of the NW training as aerobic activity; this is because the $T_{c}$ has been linked to the distribution of muscle fibre types (Dahmane, Djordjevič and Šmerdu, 2006), specifically the percentage of slow fibres type I (Šimunič et al., 2011; Travnik et al., 2013; Dahmane et al., 2005). That is, a higher Tc indicates a greater percentage of slow fibres type I.

Furthermore, a slight increase in the values of Dm of both muscles $\left(\eta^{2}=0.04\right.$ and 0.02 , respectively) has also been found, which has not proven to be significant. This is in line with the increase that occurred in athletes after 10 days of endurance training (Kerševan, Valenčič, Djordjevič and Šimunič, 2002); however, professional road cyclists have not experienced any change in their lower limbs $D_{m}$ (García-García, Cancela-Carral, Martínez-Trigo and Serrano-Gómez, 2013), and $\mathrm{D}_{\mathrm{m}}$ decreased with different lower limb strength training protocols correlated with decreases in maximal voluntary isometric contraction (de Paula et al., 2014). The $D_{m}$ is related to the changes in pitch and diameter of the muscle and to changes in the mechanical properties of the tendon (Pišot et al., 2008) particularly, an increase of $D_{m}$ value is associated with a decreased muscle tone. In fact, the TMG parameters for deltoideus are similar to woman elite kayakers (García-García et al., 2015), except in $\mathrm{D}_{\mathrm{m}}$ values, where women elite kayakers have a lower $\mathrm{D}_{\mathrm{m}}$ $(4.4 \pm 0.8 \mathrm{~mm})$, that is, a higher muscular tone, than NWG and GC groups in all assessments. However, $D_{m}$ has also been associated with neuromuscular peripheral fatigue, because although their values tend to decrease, increasing muscle stiffness, after use of force in the biceps brachii (García-Manso et al., 2012), they tend to increase their values during highly stressed resistance such as ultraendurance triathletes (García-Manso et al., 2011). Both facts are perfectly compatible, because the neuromuscular system reacts differently depending on the stimulus to which it is subjected, but both can also be taken as an immediate response after effort, not as an acute effect caused by these stimuli. A more plausible explanation for this case is that the $D_{m}$ explains, to some extent, the accumulative fatigue in NW training period in active young women. However, this question still needs to be clarified. It has been suggest that the activity of NW could add value in the use of the muscles of the shoulder and elbow, which would make the NW prove to be a more complete activity. In fact, the use of walking poles significantly increases muscle activity, measured by $\mathrm{iEMG}$, in deltoideus and triceps brachii (Shim et al., 2013). This muscular activity of the triceps brachii, during NW, increases with enhanced walking speed (Sugiyama, Kawamura, Tomita y Katamoto, 2013). Judging by the results, it appears that the duration of activity ( 2 sessions for 6 weeks), training volume ( 1.5 hours per session) and intensity (49.87\% maximal HR) has not been enough to cause a marked change in the contractile properties of the muscles of the shoulder and elbow. Furthermore, it has been suggested that in order to detect an actual change in the $\mathrm{T}_{\mathrm{c}}, \mathrm{D}_{\mathrm{m}}$, and $\mathrm{T}_{\mathrm{d}}$ parameters, differences should exceed 20\% (Ditroilo, Smith, Fairweather y Hunter, 2013). This finding indicates that a longer duration, volume and/or intensity of the NW activity would be required to cause a sharp change in muscle contractile properties in physically active young women.

This study has several limitations such as the relatively small size of the sample, no direct measures of maximal physiological parameters $\left(\mathrm{VO}_{2}\right)$ or the lack of follow-up 


\section{Martínez-Lemos, R.I.; Janura, M.; Abrantes, J.; Svoboda, Z.; García-García, O.}

measures to assess the evolution of the changes over time and, specifically, to estimate any possible recoil.

\section{CONCLUSIONS}

Our findings suggest that low to moderate intensity training conducted with a specific NW technic twice a week for 6 weeks is not sufficient to modifying the triceps brachii and deltoideus mechanical and neuromuscular response in healthy and young females.

\section{REFERENCES}

1. Atkinson, G., \& Nevill A.M. (1998). Statistical methods for assessing measurement error (reliability) in variables relevant to sports medicine. Sports Medicine, 26(4), 217-38. https://doi.org/10.2165/00007256-199826040$\underline{00002}$

2. Borg, G.A. (1982). Psychophysical bases of perceived exertion. Med Sci Sports Exerc, 14, 377-381. https://doi.org/10.1249/00005768198205000-00012

3. Church, T.S., Earnest, C.P. \& Morss, G.M. (2002). Field testing of physiological responses associated with nordic walking. Res $Q$ Exercise Sport, 73, 296-300. https://doi.org/10.1080/02701367.2002.106090 $\underline{23}$

4. Cohen, J. (1988). Statistical power analysis for the behavioral sciences. 2nd edi. Hillsdale, NJ: Lawrence Erlbaum.

5. Dechman, G., Appleby, J., Carr, M. \& Haire, M. (2012). Comparison of treadmill and overground Nordic walking. Eur J of Sport Sci, 12, 36-42.

https://doi.org/10.1080/17461391.2010.551411

6. Dahmane, R., Djordjevič, S., Šimunič, B. \& Valenčič, V. (2005). Spatial fiber type distribution in normal human muscle: Histochemical and tensiomyographical evaluation. $J$ Biomech, 38, 2451-9. https://doi.org/10.1016/j.jbiomech.2004.10.020

7. Dahmane, R., Djordjevič, S. \& Šmerdu, V. (2006). Adaptive potential of human biceps femoris muscle demonstrated by histochemical, immunohistochemical and mechanomyographical methods. Med Biol Eng and Comput, 44, 999-1006. https://doi.org/10.1007/s11517-006-0114-5

8. de Paula Simola, R.A., Harms, N., Raeder, C., Kellmann, M., Meyer, T., Pfeiffer, M. \& Ferrauti, A. (2014). Assessment of neuromuscular function after different strength training protocols using tensiomyography. $J$ Strength Cond Res, 29, 1339-1348. https://doi.org/10.1519/JSC.000000000000076 $\underline{8}$

9. Ditroilo, M., Smith, I.J., Fairweather, M.M. \& Hunter, A.M. (2013). Long-term stability of tensiomyography measured under different muscle conditions. J Electromyogr Kines, 23, 558-563. https://doi.org/10.1016/j.jelekin.2013.01.014

10. Figard-Fabre, H., Fabre, N., Leonardi, A. \& Schena, F. (2011). Efficacy of nordic walking in obesity management. Int J Sports Med, 32, 407414. https://doi.org/10.1055/s-0030-1268461

11. Figard-Fabre, H., Fabre, N., Leonardi, A., \& Schena, F. (2010). Physiological and perceptual responses to nordic walking in obese middleaged women in comparison with the normal walk. Eur J App Phys, 108, 1141-1151. https://doi.org/10.1007/s00421-009-1315-z

12. Fritschi, J.O., Brown, W.J, Laukkanen, R. \& Uffelen, J.G.Z. (2012). The effects of pole walking on health in adults: A systematic review. Scand J Med \& Sci Sports, 22, 70-78. https://doi.org/10.1111/j.16000838.2012.01495.x

13. García-García O, Cuba-Dorado A, FernándezRedondo D, López-Chicharro J. (2018). Neuromuscular parameters predict the performance in an incremental cycling test. Int J Sports Med, (12), 909-915. doi: 10.1055/a0644-3784. Epub 2018 Aug 7.

14. García-García, O., Cancela-Carral, J.M. \& Huelin Trillo, F. (2015). Neuromuscular profile of top level women kayakers, assessed through tensiomyography. J Strength Cond Res, 29(3), 844-853.

https://doi.org/10.1519/JSC.000000000000070 $\underline{2}$

15. García-García, O., Cancela-Carral, J.M., Martínez-Trigo, R. \& Serrano-Gómez, V. (2013). Differences in the properties of the knee 


\section{Nordic walking training in youth females}

extensor and flexor muscles in professional road cyclists during the season. $J$ Strength Cond Res, 27 , $2760-2767$ https://doi.org/10.1519/JSC.0b013e31828155c $\underline{\mathrm{d}}$

16. Garcia-Garcia, O., Hernandez Mendo, A., Serrano Gomez, V., \& Morales-Sanchez, V. (2013). Application of the generalizability theory of tensiomyography analysis of professional road cyclists. Revista de Psicología del Deporte, 22(1), 53-60.

17. García-García, O., Serrano-Gómez, V., y Martínez-Lemos, R. (2011). Tensiomiografía. Un método para evaluar las propiedades contráctiles de los músculos: Evaluación de los flexores y extensores del tronco en mujeres jóvenes. Cuadernos de psicología del deporte, 11(2), 63-69.

18. García-Manso, J.M, Rodríguez-Ruíz, D., Rodríguez-Matoso, D., de Saa, Y., Sarmiento, S. \& Quiroga M. (2011). Assessment of muscle fatigue after an ultra-endurance triathlon using tensiomyography (TMG). J Sports Sci, 29, 619626.

https://doi.org/10.1080/02640414.2010.548822

19. García-Manso, J.M., Rodríguez-Matoso, D., Sarmiento, S., de Saa, Y., Vaamonde, D., Rodríguez-Ruiz, D. \& Da Silva-Grigoletto M.E. (2012). Effect of high-load and high-volume resistance exercise on the tensiomyographic twitch response of biceps brachii. $J$ Electromyogr Kinesiol, 22, 612-9. https://doi.org/10.1016/j.jelekin.2012.01.005

20. Gulati, M., Shaw, L.J., Thisted, R.A., Black, H.R., Merz, C.B. \& Arnsdorf M.F. (2010). Heart rate response to exercise stress testing in asymptomatic women. The St. James women take heart project. Circulation, 122, 130-137. https://doi.org/10.1161/CIRCULATIONAHA. 110.939249

21. Hagner, W., Hagner-Derengowska, M., Wiacek, M. \& Zubrzycki, I.Z. (2009). Changes in level of $\mathrm{VO}_{2} \mathrm{max}$, blood lipids, and waist circumference in the response to moderate endurance training as a function of ovarian aging. Menopause, 16(5), 1009-1013. https://doi.org/10.1097/gme.0b013e31819c092 $\underline{4}$

22. Haskell, W.L., Lee, .IM., Pate, R.R., Powell,
K.E., Blair, S.N., Franklin, B.A. \& Bauman A. (2007). Physical activity and public health: updated recommendation for adults from the American College of Sports Medicine and the American Heart Association. Circulation, 116, 1081 .

https://doi.org/10.1161/CIRCULATIONAHA. 107.185649

23. Kerševan, K., Valenčič, V., Djordjevič, S. \& Šimunič, B. (2002). The muscle adaptation process as a result of pathological changes or specific training procedures. Cell \& Molr Biol Let, 7, 367-369.

24. Kukkonen-Harjula, K., Hiilloskorpi, H., Manttari, A., Pasanen, M., Parkkari, J., Suni, J. \& Laukkanen, R. (2007). Self-guided brisk walking training with or without poles: A randomized-controlled trial in middle-aged women. Scand J Med \& Sci Sports, 17, 316-323. https://doi.org/10.1111/j.16000838.2006.00585.x

25. Macgregor, L.J., Hunter A.M., Orizio, C., Fairweather, M.M. \& Ditroilo M. (2018) Assessment of skeletal muscle contractile properties by radial displacement: the case for tensiomyography. Sports Med, 48(7), 16071620. doi: $10.1007 / \mathrm{s} 40279-018-0912-6$

26. Martínez-Lemos, R.I, García-García, O. \& Serrano-Gómez, V. (2011). Nordic walking and health: a descriptive review. Cuadernos de Psicología del Deporte, 11(2), 115-121.

27. Martín-Rodríguez, S., Loturco, .I, Hunter, A.M., Rodríguez-Ruiz, D. \& MunguíaIzquierdo D. (2017). Reliability and measurement error of tensiomyography to assess mechanical muscle function: A systematic review. J Strength Cond Res, 31(12), 3524-3536.

doi: 10.1519/JSC.0000000000002250

28. Morgulec, N. (2011). Nordic walking: a new form of adapted physical activity (a literature review). Human Movement, 12, 124-132. https://doi.org/10.2478/v10038-011-0009-7

29. Nottingham, S. \& Jurasin, A. (2002). Nordic walking for total fitness. Champaign. Illinois: Human Kinetics.

30. Pellegrini, B., Peyré-Tartaruga, L.A., Zoppirolli, C., Bortolan, L., Bacchi, E., Figard- 


\section{Martínez-Lemos, R.I.; Janura, M.; Abrantes, J.; Svoboda, Z.; García-García, O.}

Fabre, H. \& Schena, F. (2015). Exploring Muscle Activation during Nordic Walking: A Comparison between Conventional and Uphill Walking. PloS one, 10(9), e0138906. https://doi.org/10.1371/journal.pone.0138906

31. Perotto, A.O, Delagi, E.F, Lazzeti, J. \& Morrison, D. (2005). Anatomic guide for the electromyographer: the limbs. Springfield: Charles C. Thomas.

32. Pišot, R., Narici, M.V., Šimunič, B., De Boer, M., Seynnes, O., Jurdana, M., Biolo, G., Mekjavic, I.B. (2008). Whole muscle contractile parameters and thickness loss during 35-day bed rest. Eur J App Physiol, 104, 409414. https://doi.org/10.1007/s00421-008-0698$\underline{6}$

33. Saulicz, M., Saulicz, E., Myśliwiec, A., Wolny, T., Linek, P., Knapik, A. \& Rottermund J. (2015). Effect of a 4-week Nordic walking training on the physical fitness and selfassessment of the quality of health of women of the perimenopausal age. Przeglad menopauzalny= Menopause review, 14(2), 105. https://doi.org/10.5114/pm.2015.52152

34. Shim, J.M., Kwon, H.Y., Kim, H.R., Kim, B.I. \& Jung, J.H. (2013). Comparison of the effects of walking with and without nordic pole on upper extremity and lower extremity muscle activation. J Phys Therap Sci, 25, 1553-1556. https://doi.org/10.1589/jpts.25.1553

35. Šimunič, B., Degens, H., Rittweger, J., Narici, M., Mekjavi, I.B., Pišot, R. (2011). Noninvasive estimation of myosin heavy chain composition in human skeletal muscle. Med Sci Sports Exerc, 43, 1619-25. https://doi.org/10.1249/MSS.0b013e31821522 $\underline{\mathrm{d} 0}$

36. Sugiyama, K., Kawamura, M., Tomita, H. \& Katamoto, S. (2013). Oxygen uptake, heart rate, perceived exertion, and integrated electromyogram of the lower and upper extremities during level and nordic walking on a treadmill. $J$ Physiol Anthrop, 32, 1-9. https://doi.org/10.1186/1880-6805-32-2

37. Svensson, M. (2009). Nordic walking. Champaign. Illinois: Human Kinetics.

38. Travnik, L., Djordjevič, S., Rozman, S., Hribernik, M. \& Dahmane, R. (2013). Muscles within muscles: a tensiomyographic and histochemical analysis of the normal human vastus medialis longus and vastus medialis obliquus muscles. J Anat, 222, 580-587. https://doi.org/10.1111/joa.12045

39. Tschentscher, M., Niederseer, D. \& Niebauer, J. (2013). Health benefits of nordic walking: A systematic review. Am J Prev Med, 44, 76-84. https://doi.org/10.1016/j.amepre.2012.09.043

40. Uth, N., Sørensen, H., Overgaard, K. \& Pedersen, P.K. (2004) Estimation of $\mathrm{VO}_{2} \max$ from the ratio between HRmax and HRrest-the heart rate ratio method. European journal of applied physiology, 91(1), 111-115. https://doi.org/10.1007/s00421-003-0988-y

41. Wilhelm, A., Neureuther, C. \& Mittermaier, R. (2009). Técnica Nordic Alfa. In: Domingo D, editor. Manual práctico de nordic walkingmarcha nórdica. Spain: Tutor. P 22-24. 